\title{
KAJIAN ADSORPSI ION LOGAM Cr(VI) OLEH ADSORBEN KOMBINASI ARANG AKTIF SEKAM PADI DAN ZEOLIT MENGGUNAKAN METODE SOLID-PHASE SPECTROPHOTOMETRY
}

\section{THE STUDY OF Cr(VI) ION ADSORPTION BY COMBINATION ADSORBENT OF ACTIVATED RICE HULL CHARCOAL AND ZEOLITE USING SOLID-PHASE SPECTROPHOTOMETRY}

\author{
Sulistyo Saputro*, Mohammad Masykuri, Lina Mahardiani, Bhakti Mulyani and Nita Tri Wahyuni \\ Program Studi Pendidikan Kimia, FKIP, Universitas Negeri Sebelas Maret, Surakarta \\ *email: sulistyo68@yahoo.com
}

Diterima 5 Agustus 2016 disetujui 5 September 2016

\begin{abstract}
Abstrak
Penelitian ini bertujuan untuk memanfaatkan kombinasi arang aktif sekam padi dan zeolit sebagai adsorben dalam mengadsorpsi ion logam $\mathrm{Cr}(\mathrm{VI})$ dan mempelajari pengaruh komposisi adsorben kombinasi arang aktif sekam padi dan zeolit dalam mengadsorpsi ion logam $\mathrm{Cr}(\mathrm{VI})$, serta sensitivitas metode solidphase spectrophotometry (SPS) untuk menentukan penurunan kadar ion logam $\mathrm{Cr}(\mathrm{VI})$ dalam skala $\mu \mathrm{g} / \mathrm{L}$. Arang aktif sekam padi yang digunakan diperoleh melalui proses aktivasi dengan perendaman dalam larutan $\mathrm{ZnCl}_{2} 10 \%$ sedangkan zeolit menggunakan larutan $\mathrm{H}_{2} \mathrm{SO}_{4} 10 \%$. Pengontakan adsorben dengan ion logam $\mathrm{Cr}(\mathrm{VI})$ dilakukan dengan variasi komposisi adsorben arang aktif sekam padi dan zeolit 1:1, 1:2, 1:3, dan 2:1. Analisis kadar $\mathrm{Cr}(\mathrm{VI})$ dilakukan menggunakan metode solid-phase spectrophotometry (SPS). Karakterisasi arang aktif sekam padi dan zeolit dilakukan menggunakan FTIR. Hasil penelitian ini menunjukkan bahwa: (1) kombinasi arang aktif sekam padi dan zeolit dapat digunakan sebagai adsorben dalam mengadsorpsi ion logam $\mathrm{Cr}(\mathrm{VI})$ dengan kapasitas adsorpsi 0,28 $\mu \mathrm{g} / \mathrm{g}$; (2) komposisi optimum adsorben adalah 1:2 dengan persentase penyerapan sebesar 40,99\%; (3) solid-phase spectrophotometry (SPS) merupakan metode yang sensitif untuk analisis penurunan kadar ion $\mathrm{Cr}(\mathrm{VI})$ dalam tingkat $\mu \mathrm{g} / \mathrm{L}$ dengan Limit of Detection (LOD) sebesar $0,021 \mu \mathrm{g} / \mathrm{L}$.
\end{abstract}

Kata kunci : adsorpsi, $\mathrm{Cr}(\mathrm{VI})$, arang aktif sekam padi, zeolit, solid-phase spectrophotometry

\begin{abstract}
This study aims to study the use of activated rice husk charcoal and zeolite as combination adsorbents to adsorb Cr(VI) metal ions; the effect of the combination adsorbents of activated rice husk charcoal and zeolite's compositions to adsorb CrVI) metal ions; and the sensitivity of solid-phase spectrophotometry (SPS) as a method to determine the reduced levels of $\mathrm{Cr}(\mathrm{VI})$ metal ions in the level of $\mu \mathrm{g} / \mathrm{L}$. The activated rice husk charcoal used were obtained through the activation process by soaking in a solution of $\mathrm{ZnCl}_{2} 10 \%$ while the zeolite with a solution of $\mathrm{H}_{2} \mathrm{SO}_{4} 10 \%$. The contacting process of the adsorbents with $\mathrm{Cr}$ (VI) metal ions was done by varying the compositions of the activated rice husk charcoal and zeolite adsorbent, 1:1, 1:2, 1:3, and 2:1. The data analysis of the Cr(VI) level used solid-phase spectrophotometry (SPS) method. Characterization of activated rice husk charcoal and zeolite used FTIR. The results showed that: (1) a combination of activated rice husk charcoal and zeolite can be used as adsorbent to adsorb Cr(VI) metal ions with the adsorption capacity was $0,28 \mu \mathrm{gg} / \mathrm{g}$; (2) the optimum composition of adsorbents was 1:2 with the percentage of absorption was 40,99\%; (3) solid-phase spectrophotometry (SPS) is a sensitive method to determine the reduced levels of $\mathrm{Cr}(V I)$ in the level of $\mu \mathrm{g} / \mathrm{L}$ with the limit of detection $(L O D)$ was $0,021 \mu \mathrm{g} / \mathrm{L}$.
\end{abstract}

Keywords: adsorption, $\mathrm{Cr}(\mathrm{VI})$, activated rice husk charcoal, zeolite, solid-phase spectrophotometry 


\section{Pendahuluan}

Perkembangan dalam bidang industri saat ini cukup pesat. Namun dalam perkembangannya, limbah yang dihasilkan oleh kegiatan industri sering memberikan dampak buruk. Limbah perairan yang berasal dari berbagai industri seperti industri cat, gelas, pertambangan, pelapisan logam dan baterai mengandung logam berat. Logam berat tersebut tidak dapat terurai secara alami dan keberadaannya di danau maupun sungai menyebabkan logam berat terakumulasi dalam makhluk hidup sehingga dapat menyebabkan beberapa masalah pada hewan, tumbuhan dan manusia [1].

Kromium (Cr) adalah salah satu logam berat yang berasal dari limbah industri baja, tekstil, penyamakan, fotografi, zat pewarna, bahan peledak, korek api, dan mobilisasi bahan bakar. $\mathrm{Cr}$ (III) secara alami terjadi di alam, sedangkan $\mathrm{Cr}(\mathrm{VI})$ pada umumnya berasal dari proses industri [2]. $\mathrm{Cr}(\mathrm{III})$ dan $\mathrm{Cr}(\mathrm{VI})$ memiliki perbedaan yang drastis dalam sifat kimia dan aktivitas biokimia [3]. $\mathrm{Cr}(\mathrm{III})$ bersifat kurang toksik dibandingkan $\mathrm{Cr}(\mathrm{VI})$, tidak bersifat iritatif dan tidak korosif [2]. $\mathrm{Cr}$ (III) merupakan logam yang esensial bagi tubuh manusia tapi dapat bersifat toksik dalam dosis tinggi. $\mathrm{Cr}$ (III) dibutuhkan dalam metabolisme glukosa, kolesterol dan asam lemak agar dalam keadaan normal. Sedangkan Cr(VI) bersifat sangat toksik bagi manusia dan hewan bahkan bersifat karsinogen [3]. $\mathrm{Cr}(\mathrm{VI})$ dapat menyebabkan iritasi pada hidung, mata dan kulit, meningkatkan resiko kanker paru-paru, gangguan pada hati, ginjal, alat pencernaan dan sistem imunitas [2]. World Health Organization (WHO) mengatur standar batas maksimum kontaminan kromium dalam air minum adalah sebesar $0,05 \mathrm{mg} / \mathrm{L}$ [4].

Mengingat dampak negatif yang dapat ditimbulkan oleh logam kromium khususnya $\mathrm{Cr}(\mathrm{VI})$ bagi makhluk hidup dan lingkungan, maka keberadaan logam tersebut perlu diminimalisir bahkan dihilangkan [5]. Adsorpsi merupakan teknik yang efektif dalam pemurnian dan pemisahan yang digunakan di industri terutama dalam perlakuan air dan limbah perairan [6]. Menurut Reynolds dan Paul, metode adsorpsi adalah salah satu metode alternatif yang potensial karena prosesnya yang sederhana, dapat bekerja pada konsentrasi rendah, dapat di daur ulang, dan biaya yang dibutuhkan relatif murah [7].

Menurut $\mathrm{Yu}$, et al (2003), adsorpsi $\mathrm{Cr}(\mathrm{VI})$ pada limbah-limbah cair telah banyak dilaporkan menggunakan adsorben seperti, resin sintetik, arang aktif, sorben dari bahan-bahan organik (biosorben) menggunakan bahan-bahan organik mati, serta sorben dari bahan anorganik seperti zeolit, lempung dan silika [5]. Pengolahan limbah logam berat dapat dilakukan dengan menggunakan arang aktif. Karbon atau arang aktif merupakan karbon yang diberi perlakuan khusus sehingga mempunyai luas permukaan pori yang sangat besar, berkisar 300$2000 \mathrm{~m}^{2} / \mathrm{g}$ [8].

Salah satu bahan baku dalam membuat arang aktif adalah sekam padi. Sekam padi merupakan limbah pertanian yang cukup banyak dihasilkan yaitu untuk setiap 50 juta ton padi yang diproduksi dihasilkan 13 juta ton sekam padi per tahun dengan pemanfaatan yang masih sangat minimal [9]. Kandungan silika $\left(\mathrm{SiO}_{2}\right)$ pada sekam padi cukup tinggi yaitu 87-90\% [10].

Selain itu, adsorben lain yang dapat digunakan untuk meminimalisasi adanya limbah logam berat khususnya $\mathrm{Cr}(\mathrm{VI})$ adalah zeolit. Zeolit merupakan salah satu mineral yang keberadaannya melimpah namun belum dimanfaatkan secara optimal [11]. Menurut Chetam, zeolit adalah suatu mineral kristal alumina silika tetrahidrat berpori yang mempunyai struktur kerangka tiga dimensi, terbentuk oleh tetrahedral $\left[\mathrm{SiO}_{4}\right]^{4-}$ dan $\left[\mathrm{AlO}_{4}\right]^{5-}$ yang saling terhubungkan oleh atom-atom oksigen sedemikian rupa, sehingga membentuk kerangka tiga dimensi terbuka mengandung rongga-rongga. Di dalam ronga-rongga tersebut terisi oleh ion-ion logam, biasanya adalah logam-logam alkali atau alkali tanah dan molekul air yang dapat bergerak bebas [12]. Selain itu, zeolit merupakan material yang penting untuk katalis, penukar ion, adsorben dan aplikasi saringan molekuler (molecular sieve) [13].

Solid-Phase Spectrophotometry (SPS) adalah salah satu metode analisis dengan menggunakan spektrofotometer sinar UV-vis dalam bentuk fase padat yang menyerap suatu komponen sampel [3]. Metode SPS didasarkan pada pengukuran langsung sampel dari penyerapan cahaya fasa resin penukar ion yang telah menyerap spesies sampel [14]. Keuntungan metode SPS yaitu lebih sensitif daripada metode konvesional yang menggunakan instrumen mahal dan dapat menentukan kadar suatu sampel dalam air sampai kadar $\mu \mathrm{g} / \mathrm{L}$. Pada penelitian sebelumnya tentang penentuan $\mathrm{Cr}(\mathrm{VI})$ pada sampel air alam dengan metode SPS diperoleh Limit of Detection (LOD) sebesar 0,014 $\mu \mathrm{g} / \mathrm{L}$ [3].

\section{Metode Penelitian}


Alat dan Bahan. Alat-alat yang digunakan dalam penelitian ini adalah satu unit spektrofotometer sinar UV-vis K-MAC Lab.Junior, spektrofotometer FTIR Shimadzu, muffle furnace, oven dan loyang, neraca analitik, labu ukur, gelas beker, erlenmeyer, gelas ukur, pipet volume gelas beaker, gelas ukur, erlenmeyer, corong kaca, pengaduk kaca, kaca arloji, pipet tetes, aliquotting device yang dirangkai menggunakan syringe, blender, mortar dan alu, ayakan 100 mesh, krus porselin dan magnetic stirrer. Bahan-bahan yang digunakan adalah sekam padi, zeolit, larutan standar $\mathrm{Cr}(\mathrm{VI}) \quad 100 \mathrm{mg} / \mathrm{L} \quad$ (Wako, Jepang), difenilkarbazida (Wako, Jepang), $\mathrm{ZnCl}_{2}$, larutan $\mathrm{H}_{2} \mathrm{SO} 4$ (Merck), resin Muromac AG 50W-X $\mathrm{H}_{2} \mathrm{H}^{+}$ form 100-200 mesh (Wako, Jepang), akuades, aseton (Merck), kertas saring Whattman dan kertas lakmus biru.

Pembuatan adsorben arang aktif sekam padi. Sekam padi dibersihkan dan dicuci dengan menggunakan akuades, lalu dioven pada suhu $105^{\circ} \mathrm{C}$ selama 24 jam. Selanjutnya sekam padi dipanaskan dalam muffle furnace pada suhu $350^{\circ} \mathrm{C}$ selama 1,5 jam. Arang sekam padi dihaluskan dengan mortar dan alu lalu diayak dengan ayakan 100 mesh. Arang sekam padi direndam dalam larutan $\mathrm{ZnCl}_{2} \quad 10 \%$ selama 24 jam. Kemudian dicuci dan disaring hingga $\mathrm{pH}$ filtrat netral. Adsorben dioven pada $105^{\circ} \mathrm{C}$ selama 24 jam.

Pembuatan adsorben zeolit. Zeolit dibersihkan dan dicuci dengan menggunakan akuades, lalu dioven pada suhu $105^{\circ} \mathrm{C}$ selama 24 jam. Selanjutnya zeolit dihaluskan dengan mortar dan alu lalu diayak menggunakan ayakan 100 mesh. Zeolit direndam dalam larutan $\mathrm{H}_{2} \mathrm{SO}_{4} 10 \%$ selama 24 jam. Kemudian dicuci dan disaring hingga $\mathrm{pH}$ filtrat netral. Adsorben dioven pada $105^{\circ} \mathrm{C}$ selama 24 jam.

Persiapan resin. Resin Muromac AG 50W-X2 100-200 mesh dilarutkan dalam sejumlah akuades dan mendiamkannya beberapa saat hingga resin menjadi lebih mengembang.

Pembuatan larutan pengompleks difenilkarbazia $(D P C)$. Larutan DPC dibuat dengan melarutkan 0,25 gram DPC dalam $100 \mathrm{~mL}$ aseton.

Pembuatan Kurva Standar Cr(VI). Larutan standard $\mathrm{Cr}(\mathrm{VI})$ dibuat dengan konsentrasi $0 \mu \mathrm{g} / \mathrm{L}$, $2 \mu \mathrm{g} / \mathrm{L}, 4 \mu \mathrm{g} / \mathrm{L}, 8 \mu \mathrm{g} / \mathrm{L}$ masing-masing $20 \mathrm{ml}$. Menambahkan $1 \mathrm{~mL}$ larutan $\mathrm{H}_{2} \mathrm{SO}_{4} 0,5 \mathrm{M}, 1 \mathrm{~mL}$ larutan 1,5-diphenylcarbazide (DPC) dan $0,06 \mathrm{ml}$ resin lalu distirer selama 20 menit. Menganalisis menggunakan spektrofotometer UV-Vis pada panjang gelombang $540 \mathrm{~nm}$ dan $682 \mathrm{~nm}$. Selisih absorbansi dihitung dengan formula $\Delta \mathrm{A}=\mathrm{A}_{540 \mathrm{~nm}}$ $\mathrm{A}_{682 \mathrm{~nm}}$, dan diplot sebagai $\Delta \mathrm{A}$ vs konsentrasi.

Penentuan spesi $\mathrm{Cr}(\mathrm{VI})$ dalam limbah cair simulasi. Larutan limbah cair simulasi $\mathrm{Cr}(\mathrm{VI})$ disiapkan sebanyak $20 \mathrm{~mL}$ dan ditambah $1 \mathrm{~mL}$ larutan $\mathrm{H}_{2} \mathrm{SO}_{4} 0,5 \mathrm{M}, 1 \mathrm{~mL}$ larutan DPC $0,25 \%$ dan $0,06 \mathrm{~mL}$ resin lalu distirer selama 20 menit dan dianalisis dengan spektrofotometer UV-Vis pada panjang gelombang $540 \mathrm{~nm}$ dan $682 \mathrm{~nm}$. $\Delta$ A yang diperoleh akan disubstitusikan dalam persamaan kurva standar $\mathrm{Cr} \mathrm{Cr}(\mathrm{VI}) \quad(\Delta \mathrm{A}$ vs konsentrasi), sehingga spesi ion $\mathrm{Cr}(\mathrm{VI})$ dalam limbah dapat diketahui.

Penentuan komposisi adsorben optimum dalam penurunan kadar ion $\mathrm{Cr}(\mathrm{VI})$. Kombinasi adsorben arang aktif sekam padi dan zeolit masingmasing sebanyak 0,5 gram dengan variasi komposisi adsorben 1:1, 1:2, 1:3, dan 2:1 ditambah dengan limbah cair simulasi $\mathrm{Cr}(\mathrm{VI}) 50 \mu \mathrm{g} / \mathrm{L}$ lalu distirer selama 20 menit. Masing-masing kombinasi lalu disaring dengan kertas saring whatman. Kemudian filtrat yang dihasilkan diambil sebanyak $5 \mathrm{~mL}$ untuk diencerkan dengan akuades sampai volumenya $50 \mathrm{~mL}$. Selanjutnya, filtrat yang sudah diencerkan diambil sebanyak $20 \mathrm{~mL}$ ditambah dengan $1 \mathrm{~mL} \mathrm{H}_{2} \mathrm{SO}_{4} 0,5 \mathrm{M}, 1 \mathrm{~mL}$ larutan DPC $0,25 \%$ dan $0,06 \mathrm{ml}$ resin lalu distirer selama 20 menit kemudian dianalisis menggunakan spektrofotometer UV-Vis dengan panjang gelombang $540 \mathrm{~nm}$ dan $682 \mathrm{~nm}$.

Penentuan batas deteksi. Pada penentuan batas deteksi digunakan metode $3 \sigma(\sigma=$ standar deviasi). Larutan blangko berupa akuades sebanyak 5 kali, lalu masing-masing ditambahkan $1 \mathrm{~mL} \mathrm{H}_{2} \mathrm{SO}_{4} 0,5$ M, $1 \mathrm{~mL}$ larutan DPC $0,25 \%$ dan resin sebanyak $0,06 \mathrm{ml}$ lalu distriter selama 20 menit. Kemudian, dianalisis dengan spektrofotometer UV-Vis dengan panjang gelombang $540 \mathrm{~nm}$ dan $682 \mathrm{~nm}$.

\section{Hasil dan Pembahasan}

\section{a. Pembuatan adsorben arang aktif sekam padi}

Proses pembuatan adsorben arang aktif sekam padi terdiri dari tiga tahap yaitu, tahap dehidrasi, karbonisasi dan aktivasi. Pada tahap dehidrasi, sekam padi dicuci dengan akuades sampai bersih untuk menghilangkan pengotor. Lalu, pada tahap karbonisasi, sekam padi yang sudah dikeringkan, dipanaskan ke dalam muffle furnace pada suhu $350^{\circ} \mathrm{C}$ selama 1,5 jam. Hasil dari tahap karbonisasi yaitu arang sekam padi yang berwarna hitam. Kemudian, arang sekam padi dihaluskan dan diayak menggunakan ayakan 100 mesh. Hasilnya 
berupa serbuk arang sekam padi berwarna hitam dengan tekstur halus berukuran 100 mesh. Tahapan selanjutnya yaitu aktivasi adsorben arang sekam padi dengan merendam arang sekam padi dalam gelas beker berisi larutan $\mathrm{ZnCl}_{2} 10 \%$ pada suhu kamar selama 24 jam. Untuk mengetahui perubahan struktur dan gugus fungsi pada adsorben arang aktif sekam padi sebelum dan setelah diaktivasi dilakukan karakterisasi menggunakan instrumen FTIR (Gambar 1).

Sekam padi merupakan kulit atau lapisan terluar padi berwarna kekuningan atau keemasan yang membungkus butir beras. Sekam padi mengandung selulosa yang dapat dikonversi menjadi arang [15] .Selain itu, sekam padi mengandung silika $\left(\mathrm{SiO}_{2}\right)$ cukup tinggi yaitu 87$90 \%$ [10]. Pembuatan adsorben arang aktif sekam padi terdiri dari tiga tahap yaitu, dehidrasi, karbonisasi dan aktivasi.

Pada tahap dehidrasi, sekam padi dicuci dengan menggunakan akuades, lalu dioven pada suhu $105^{\circ} \mathrm{C}$ selama 24 jam. Tahap ini bertujuan untuk menghilangkan kadar air sisa pencucian sekam padi agar sekam padi benar-benar kering. Kemudian, tahap karbonisasi dilakukan dengan memanaskan sekam padi dalam muffle furnace pada suhu $350{ }^{\circ} \mathrm{C}$ selama 1,5 jam untuk menghasilkan arang sekam padi. Selama proses karbonisasi, unsur-unsur selain karbon seperti hidrogen dan oksigen dibebaskan dalam bentuk gas. Arang sekam padi yang diperoleh dihaluskan dengan mortar dan alu, lalu diayak menggunakan ayakan 100 mesh. Hasilnya berupa serbuk arang sekam padi berwarna hitam dengan tekstur halus berukuran 100 mesh. Pada tahap aktivasi, arang sekam padi direndam dengan menggunakan larutan $\mathrm{ZnCl}_{2} \quad 10 \%$ selama 24 jam. Tahap aktivasi bertujuan memperluas permukaan karbon menjadi lebih besar karena hidrokarbon dan zat-zat pengotor lainnya yang menyumbat pori-pori terbebaskan.

Hasil perendaman adsorben dengan larutan aktivator lalu disaring dengan kertas saring Whattman sehingga terbentuk filtrat dan residu. Residu yang dihasilkan kemudian dibilas dengan akuades sampai $\mathrm{pH}$ netral. Pengujian dilakukan dengan kertas lakmus biru. Kemudian, mengeringkan dalam oven dengan suhu $105^{\circ} \mathrm{C}$ selama 24 jam. Hasil yang diperoleh berupa arang aktif sekam padi berwarna hitam dengan tekstur halus yang kemudian akan dikombinasikan dengan zeolit sebagai adsorben kombinasi ion logam $\mathrm{Cr}(\mathrm{VI})$.

(a)

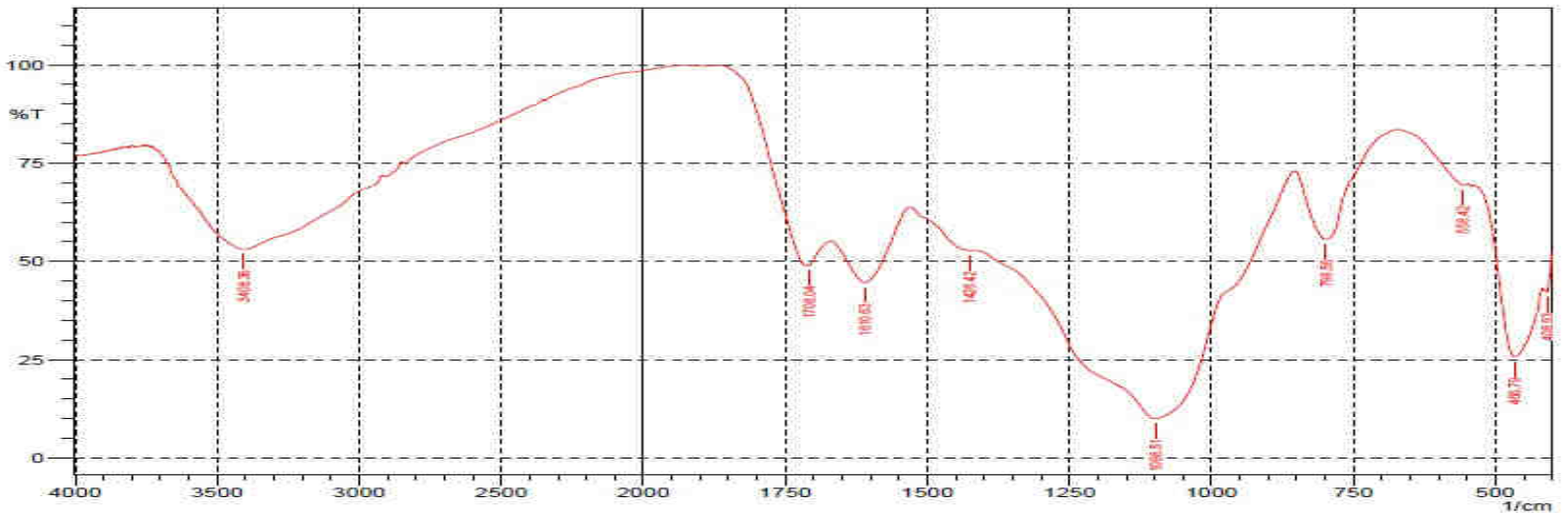

(b)

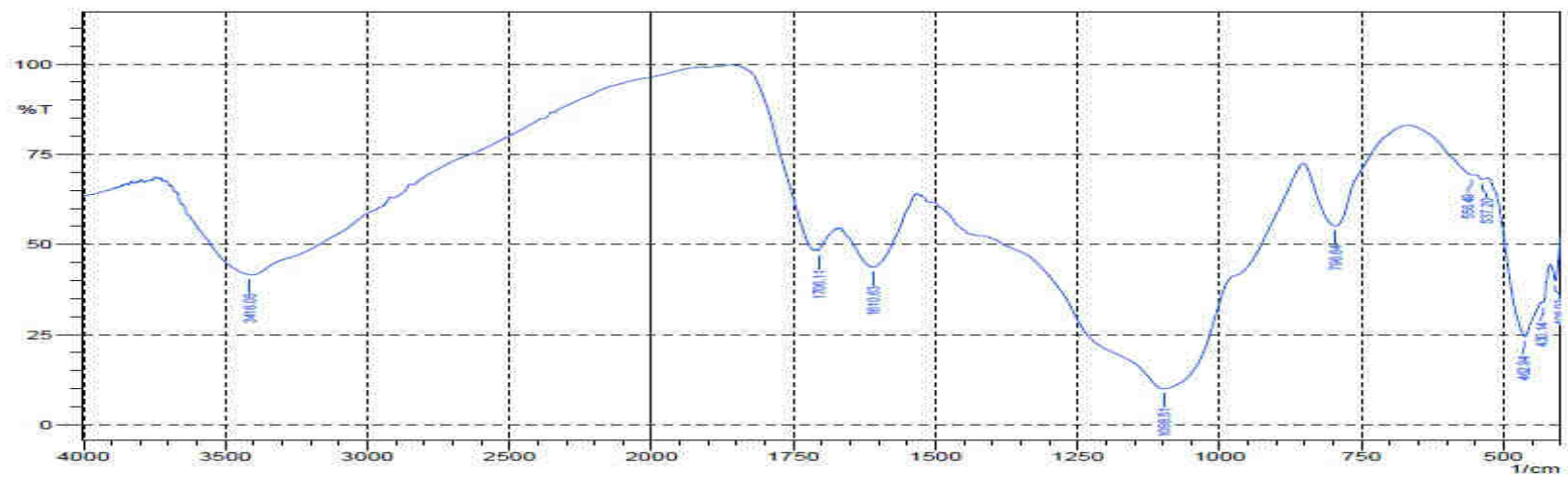

Gambar 1. Spektra FTIR Arang Sekam Padi. (a) Sebelum Aktivasi; (b) Setelah Aktivasi 


\section{b. Pembuatan adsorben zeolit}

Pembuatan zeolit dilakukan dengan cara membersihkan zeolit dengan akuades untuk menghilangkan pengotor. Lalu, zeolit dikeringkan pada oven pada suhu $105^{\circ} \mathrm{C}$ selama 24 jam. Zeolit dihaluskan dengan mortar, alu dan blender. Kemudian, diayak dengan ayakan 100 mesh. Hasilnya berupa serbuk zeolit berwarna putih keruh dengan tekstur halus berukuran 100 mesh. Selanjutnya, aktivasi zeolit dengan cara merendam zeolit dengan $\mathrm{H}_{2} \mathrm{SO}_{4} 10 \%$ selama 24 jam pada suhu kamar. Untuk mengetahui perubahan struktur dan gugus fungsi pada adsorben zeolit setelah diaktivasi dilakukan karakterisasi menggunakan instrumen FTIR (Gambar 2).

Zeolit adalah suatu mineral ditemukan dalam celah-celah ataupun rekahan batuan akibat dari aktifitas vulkanik yang banyak mengandung silika [16]. Zeolit dibersihkan dengan akuades untuk menghilangkan pengotor. Lalu, zeolit dikeringkan pada suhu $105^{\circ} \mathrm{C}$ selama 24 jam agar didapatkan zeolit dalam keadaan kering. Kemudian, zeolit dihaluskan dengan mortar, alu dan blender serta diayak menggunakan ayakan 100 mesh. Hasil yang diperoleh berupa serbuk halus zeolit berwarna putih keruh berukuran 100 mesh.

Pada tahap aktivasi, zeolit direndam dengan menggunakan $\mathrm{H}_{2} \mathrm{SO}_{4} 10 \%$ selama 24 jam pada suhu kamar. Tahap aktivasi pada zeolit bertujuan memperbesar luas permukaan pori-pori, melarutkan beberapa ion logam yang tidak bermanfaat dan mengganti dengan ion logam yang diinginkan. Kemudian, adsorben yang dihasilkan disaring dengan kertas saring. Residu dibilas dengan akuades hingga filtratnya netral. Zeolit yang telah diaktivasi dikeringkan dalam oven pada suhu pada suhu $105^{\circ} \mathrm{C}$ selama 24 jam. Hasil yang diperoleh berupa zeolit berwarna putih susu yang kemudian akan dikombinasikan dengan arang aktif sekam padi sebagai adsorben kombinasi ion logam $\mathrm{Cr}(\mathrm{VI})$.

(a)

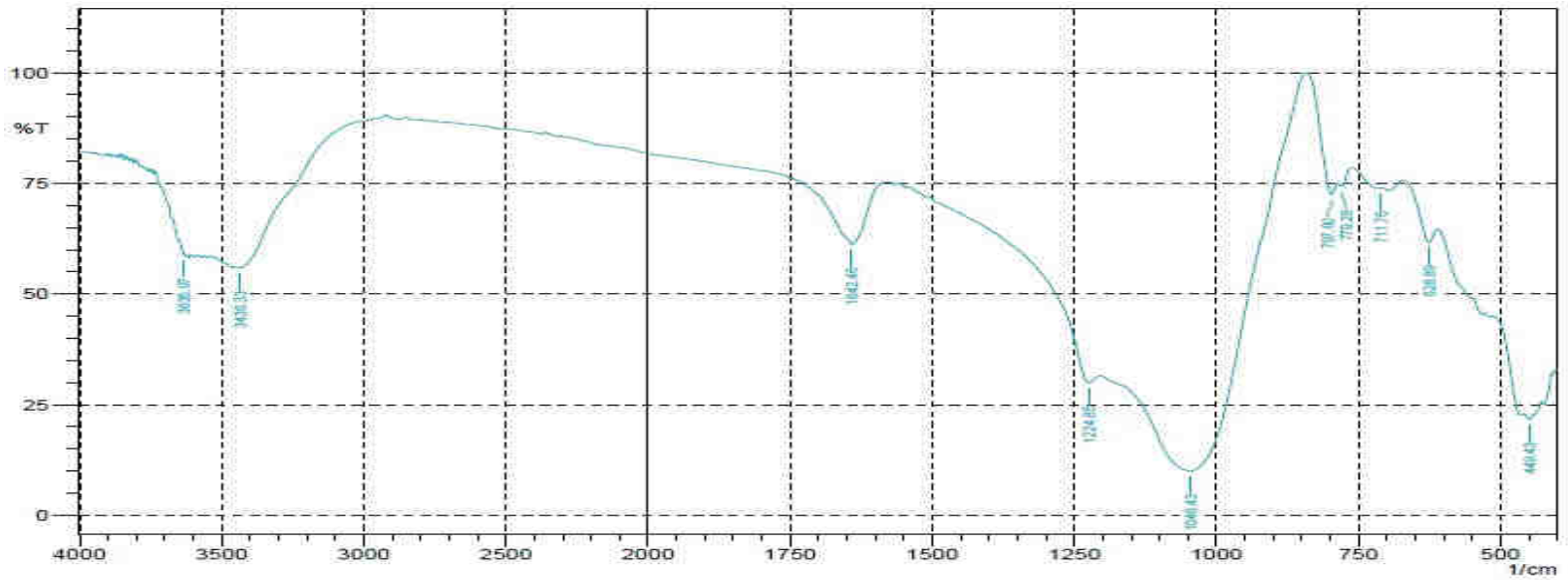

(b)

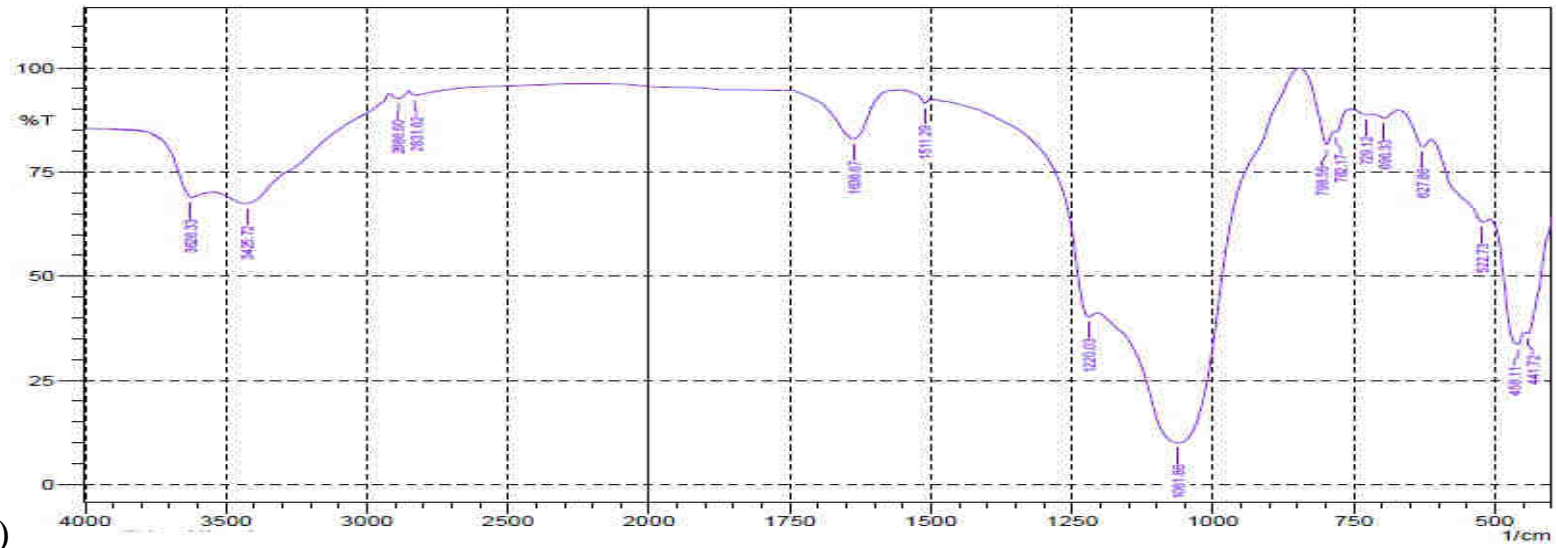

Gambar 2. Spektra FTIR Zeolit. (a) Sebelum Aktivasi; (b) Setelah Aktivasi 
Hasil uji FTIR adsorben arang aktif sekam padi sebelum aktivasi diperoleh hasil bahwa terdapat gugus $-\mathrm{OH}$ dari $\mathrm{Si}-\mathrm{OH}, \mathrm{C}=\mathrm{O}, \mathrm{C}=\mathrm{C}$ aromatis, Si-O dari Si-O-Si. Pada adsorben arang aktif sekam padi setelah aktivasi, terjadi pergeseran bilangan gelombang tetapi gugus yang ditunjukkan tidak jauh berbeda. Sedangkan hasil uji FTIR adsorben zeolit sebelum aktivasi diperoleh hasil bahwa terdapat gugus $-\mathrm{NH}, \mathrm{C}=\mathrm{O}$ dan $\mathrm{Si}-\mathrm{O}$ dari Si$\mathrm{O}-\mathrm{Si}$. . Pada adsorben zeolit setelah aktivasi, terjadi pergeseran bilangan gelombang namun gugus yang ditunjukkan tidak jauh berbeda. Adanya pergeseran gugus-gugus pada masing-masing adsorben tersebut menunjukkan bahwa gugus-gugus fungsi tersebut berperan dalam proses aktivasi pada masing-masing adsorben dan adsorpsi terhadap ion logam $\mathrm{Cr}(\mathrm{VI})$.

\section{c. Penentuan Kurva Standar Cr(VI)}

Berdasarkan penelitian diperoleh grafik kurva standar (Gambar 3) dengan persamaan y $=0,0264 \mathrm{x}$ $+0,1058$ di mana $\mathrm{y}$ adalah $\Delta \mathrm{A}$ dan $\mathrm{x}$ adalah konsentrasi. Persamaan tersebut digunakan untuk menentukan konsentrasi $\mathrm{Cr}(\mathrm{VI})$ yang terkandung dalam limbah cair simulasi.

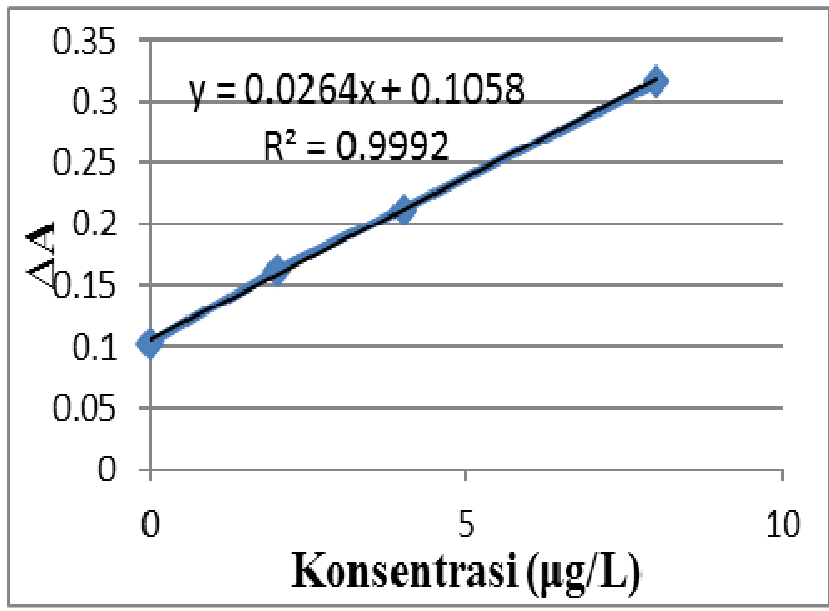

Gambar 3. Kurva Standar Cr(VI)

Tabel 1. Hasil Penentuan Kadar Cr(VI) dalam Limbah Cair Simulasi

\begin{tabular}{ccc}
\hline Sampel & $\boldsymbol{\Delta A}$ & $\begin{array}{c}{[\mathbf{C r}(\mathbf{V I})]} \\
(\boldsymbol{\mu g} / \mathbf{L})\end{array}$ \\
\hline Sampel & 0,2422 & 51,74 \\
$\mathrm{Cr}(\mathrm{VI})$ & & \\
\hline
\end{tabular}

\section{d. Penentuan Kurva Standar Cr(VI) dalam limbah cair simulasi}

Berdasarkan hasil perhitungan diperoleh kadar $\mathrm{Cr}(\mathrm{VI})$ dalam limbah cair simulasi sebesar 51,74 $\mu \mathrm{g} / \mathrm{L}$. Solid-Phase Spectrophotometry (SPS) adalah salah satu metode analisis menggunakan spektrofotometer sinar UV-vis dalam bentuk fase padat yang menyerap suatu komponen sampel [3]. Metode SPS didasarkan pada pengukuran langsung sampel dari penyerapan cahaya fasa resin penukar ion yang telah menyerap spesies sampel [14]. Dalam penentuan konsentrasi sampel, sampel yang akan diuji ditambah dengan zat pengompleks kemudian menjadi senyawa kompleks. Kemudian ditambahkan resin untuk menyerap sampel tersebut ke dalamnya sehingga menjadi fase padat. Pada penelitian ini menggunakan 1,5-diphenylcarbazide (DPC) sebagai larutan pengompleks $\mathrm{Cr}(\mathrm{VI}) . \mathrm{Cr}(\mathrm{VI})$ dalam bentuk kompleks ini yang diabsorb oleh resin penukar kation Muromac kemudian dianalisis menggunakan SPS.

Penentuan konsentrasi Cr(VI) dalam limbah simulasi dilakukan dengan membuat kurva standar larutan $\mathrm{Cr}(\mathrm{VI})$ pada berbagai variasi konsentrasi yaitu $0 \mu \mathrm{g} / \mathrm{L}, 2 \mu \mathrm{g} / \mathrm{L}, 4 \mu \mathrm{g} / \mathrm{L}$, dan $8 \mu \mathrm{g} / \mathrm{L}$. Berdasarkan kurva standar diperoleh suatu persamaan yaitu $\mathrm{y}=0,0264 \mathrm{x}+0,1058$ di mana $\mathrm{y}$ adalah $\Delta \mathrm{A}$ dan $\mathrm{x}$ adalah konsentrasi. Persamaan tersebut digunakan untuk menentukan konsentrasi $\mathrm{Cr}(\mathrm{VI})$ yang terkandung dalam limbah cair simulasi dengan cara mensubstitusikan $\Delta \mathrm{A}$ yang diperoleh ke dalam kurva standar $\mathrm{Cr}(\mathrm{VI})$ sehingga konsentrasi $\mathrm{Cr}(\mathrm{VI})$ dalam limbah cair simulasi dapat diketahui. Berdasarkan hasil perhitungan diperoleh konsentrasi $\mathrm{Cr}(\mathrm{VI})$ dalam sampel adalah sebesar $51,74 \mu \mathrm{g} / \mathrm{L}$.

Penentuan LOD dilakukan menggunakan beberapa larutan blangko berupa akuades lalu menentukan standar deviasinya. LOD ditentukan dengan $3 \sigma(\sigma=$ standar deviasi) [3]. Berdasarkan penelitian diperoleh batas deteksi atau LOD metode SPS adalah sebesar $0,021 \mu \mathrm{g} / \mathrm{L}$. Sehingga dapat disimpulkan bahwa SPS merupakan metode yang sensitif dalam menganalisis kadar suatu sampel sampai tingkat $\mu \mathrm{g} / \mathrm{L}$.

\section{e. Penentuan komposisi optimum adsorben kombinasi arang aktif sekam padi dan zeolit \\ Penentuan komposisi optimum adsorben arang} aktif sekam padi dan zeolit dapat dilihat pada Gambar 4. Penentuan komposisi optimum adsorben kombinasi arang aktif sekam padi dan zeolit dilakukan untuk mengetahui komposisi adsorben campuran arang aktif sekam padi dan zeolit yang dibutuhkan untuk menyerap ion logam $\mathrm{Cr}(\mathrm{VI})$ 
secara maksimum sampai terjadi keadaan jenuh. Penentuan komposisi optimum adsorben dilakukan dengan cara mengontakan sampel $\mathrm{Cr}(\mathrm{VI})$ dengan masing-masing variasi komposisi adsorben yang digunakan yaitu arang aktif sekam padi dan zeolit $1: 1,1: 2,1: 3$, dan $2: 1$.

Berdasarkan hasil analisis penentuan komposisi optimum adsorben (Gambar 4) didapatkan bahwa konsentrasi $\mathrm{Cr}(\mathrm{VI})$ yang terserap dari komposisi adsorben 1:1 ke 1:2 mengalami kenaikan, tetapi pada komposisi 1:3 dan 2:1 mengalami penurunan. Hal ini menunjukkan bahwa komposisi adsorben dengan jumlah zeolit yang lebih banyak menghasilkan penyerapan ion logam $\mathrm{Cr}(\mathrm{VI})$ lebih tinggi daripada komposisi dengan jumlah arang aktif yang lebih banyak. Hal tersebut disebabkan struktur zeolit yang berongga mengakibatkan kation atau molekul berukuran lebih kecil atau sama dengan rongga dapat masuk dan terjebak. Selain itu, zeolit dapat mempertukarkan ion. Kation tersebut dapat bergerak bebas di dalam rongga dan dapat dipertukarkan dengan kation logam lain dengan jumlah yang sama. Sedangkan karbon mempunyai sifat sebagai adsorben yang dapat mengadsorpsi gas dan senyawa-senyawa kimia tertentu atau dengan kata lain sifat adsorpsinya selektif, tergantung pada besar atau volume pori-pori dan luas permukaan [16].

Pada penelitian ini, komposisi optimum adsorben dalam menyerap ion logam $\mathrm{Cr}(\mathrm{VI})$ adalah 1:2. Hal tersebut dikarenakan pada komposisi adsorben campuran arang aktif sekam padi dan zeolit tersebut terjadi kesetimbangan antara adsorben dan adsorbat sehingga dapat menyerap ion logam $\mathrm{Cr}(\mathrm{VI})$ dengan persentase tertinggi. Berdasarkan data yang diperoleh, komposisi adsorben 1:2 memiliki persentase penyerapan lebih tinggi daripada 1:3, hal tersebut dimungkinkan terjadi karena situs aktif dalam jumlah besar membutuhkan waktu kesetimbangan yang lebih lama sehingga memengaruhi daya serap adsorben terhadap ion logam $\mathrm{Cr}(\mathrm{VI})$.

Berdasarkan hasil analisis tersebut, diperoleh bahwa komposisi optimum adsorben untuk menyerap ion logam $\mathrm{Cr}(\mathrm{VI})$ adalah 1:2. Pada komposisi 1:2 dapat menurunkan ion logam $\mathrm{Cr}(\mathrm{VI})$ sebesar $21,21 \mu \mathrm{g} / \mathrm{L}$ dengan persentase penyerapan sebesar 40,99\%. Adsorben kombinasi arang aktif sekam padi dan zeolit dapat digunakan sebagai adsorben ion logam $\mathrm{Cr}(\mathrm{VI})$ dengan kapasitas adsorpsi sebesar $0,28 \mu \mathrm{g} / \mathrm{g}$.

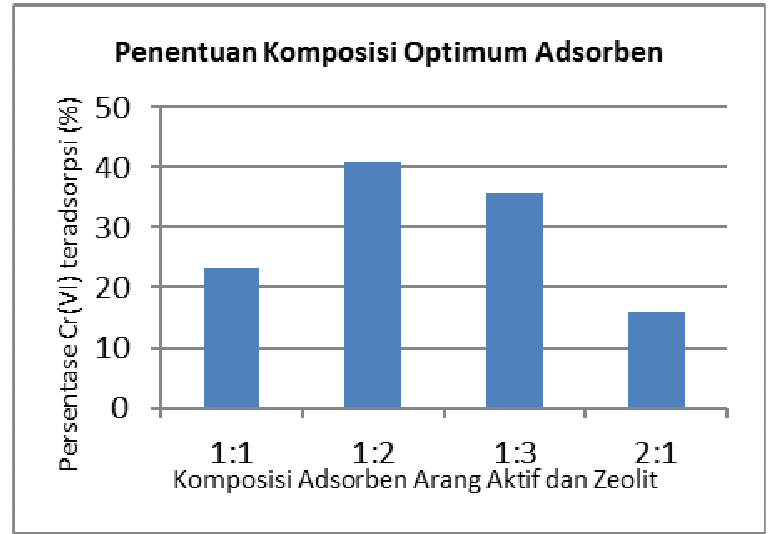

Gambar 4. Komposisi adsorben terhadap $\mathrm{Cr}(\mathrm{VI})$

\section{f. Penentuan batas deteksi}

Penentuan LOD dilakukan dengan cara menguji beberapa larutan blangko berupa akuades. Kemudian menghitung standar deviasinya, LOD dihitung dengan cara $3 \sigma(\sigma=$ standar deviasi) [3]. LOD yang diperoleh adalah sebesar $0,021 \mu \mathrm{g} / \mathrm{L}$.

\section{Simpulan}

Hasil penelitian ini menunjukkan bahwa kombinasi arang aktif sekam padi dan zeolit dapat digunakan sebagai adsorben dalam mengadsorpsi ion logam $\mathrm{Cr}(\mathrm{VI})$ dengan kapasitas adsorpsi 0,28 $\mu \mathrm{g} / \mathrm{g}$; terdapat pengaruh komposisi terhadap adsorben kombinasi arang aktif sekam padi dan zeolit untuk mengadsorpsi ion logam $\mathrm{Cr}(\mathrm{VI})$ dalam sampel, komposisi adsorben optimum adalah 1:2 dengan persentase penyerapan sebesar 40,99\%; dan metode solid-phase spectrophotometry (SPS) merupakan metode yang sensitif untuk analisis penurunan kadar ion $\mathrm{Cr}(\mathrm{VI})$ hasil adsorpsi adsorben kombinasi arang aktif sekam padi dan zeolit dalam tingkat $\mu \mathrm{g} / \mathrm{L}$ dengan Limit of Detection (LOD) sebesar 0,021 $\mu \mathrm{g} / \mathrm{L}$.

\section{Pustaka}

[1] Bernard, E., Jimoh, A., \& Odigure, J.O. (2013). Heavy Metals Removal from Industrial Wastewater by Activated Carbon Prepared from Coconut Shell. Research Journal of Chemical Sciences, 3 (8), 3-9

[2] Widowati, W., Sastiono, A., \& Jusuf, R. (2008). Efek Toksik Logam: Pencegahan dan Penanggulangan Pencemaran. Yogyakarta: Andi.

[3] Saputro, S., et al. (2009). Improved Solidphase Spectrophotometry for the Microdetermination of Chromium(VI) in 
Natural Water. Analytical Sciences, 25, 14451450

[4] Heydari (2013). Adsorption of Chromium Ions from Aqueous Solution by Carbon Adsorbent. International Journal of Environmental, Ecological, Geological and Marine Engineering, 7 (12), 632-635

[5] Giri, H.P.D., Sudiarta, I.W., \& Asih, I.A.R.A. (2014). Optimasi Adsorpsi Cr(VI) pada Silika Gel dari Abu Sekam Padi Termodifikasi Difenilkarbazida (Si-DPZida). Jurnal Kimia 8 (2), 198-204

[6] Singh, S.R. \& Singh, A.P. (2012). Treatment of Water Containing Chromium (VI) Using Rice Husk Carbon As a New Low Cost Adsorbent. International Journal of Environmental Research, 6 (4), 917-924

[7] Suminten, N.K., Sudiarta, I.W., \& Simpen, I.N. (2014). Adsorpsi Ion Logam Cr(III) pada Silika Gel dari Abu Sekam Padi Termodifikasi Ligan Difenilkarbazon (SiDPZon). Jurnal Kimia, 8 (2), 231-236

[8] Danarto, Y.C. \& Samun, T. (2008). Pengaruh Aktivasi Karbon dari Sekam Padi pada Proses Adsorpsi Logam Cr(VI). Ekuilibrium, 7 (1), 13-16

[9] Purwaningsih, D. (2009). Adsorpsi Multi Logam $\mathrm{Ag}(\mathrm{I}), \mathrm{Cr}(\mathrm{III}), \mathrm{Cu}(\mathrm{II})$ dan Ni(II) pada Hibrida Etilendiaminosilika dari Abu Sekam Padi. Jurnal Penelitian Saintek, 14 (1), 59-76
[10] Zulti, F., Dahlan, K., \& Sugita, P. (2012). Adsorptiom of Waste Metal Cr(VI) with Composite Membranes (Chitosan-Silica Rice Husks). Makara Journal of Science, 16 (3), 163-168

[11] Sani, A., Rosita, A., \& Rakhmawaty, D. (2009). Pembuatan Fotokatalis $\mathrm{TiO}_{2}$-Zeolit Alam Asal Tasikmalaya untuk Fotodegradasi Metylene Blue. Jurnal Zeolit Indonesia, 8 (1), 6-14

[12] Lestari, D.Y. (2010). Kajian Modifikasi dan Karakterisasi Zeolit Alam dari Berbagai Negara. Prosiding Seminar Nasional Kimia dan Pendidikan Kimia. FMIPA. UNY

[13] Jumaeri (2009). Pengaruh Konsentrasi $\mathrm{NaOH}$ dan Temperatur pada Sintesis Zeolit dari Abu Layang secara Alkali Hidrotermal. Jurnal Zeolit Indonesia, 8 (1), 22-32

[14] Yoshimura, K. \& Waki, H. (1985). IonExchanger Phase Absorptiometry for Trace Analysis. Talanta, 32 (5), 245-352

[15] Siahaan, S., Hutapea, M., \& Hasibuan, R. (2013). Penentuan Kondisi Optimum Suhu dan Waktu Karbonisasi pada Pembuatan Arang dari Sekam Padi. Jurnal Teknik Kimia USU, 2 (1), 26-30

[16]Nugroho, W. \& Purwoto, S. (2013). Removal Klorida, TDS dan Besi pada Air Payau melalui Penukar Ion dan Filtrasi Campuran Zeolit Aktif dengan Karbon Aktif. Jurnal Teknik WAKTU, 11 (1), 47-59 